\title{
Determination of surface runoff from the modelled area
}

\author{
Tatiana Kaletova $^{1 *}$, Zuzana Nemetova ${ }^{2}$ \\ ${ }^{1}$ Slovak University of Agriculture in Nitra, Trieda Andreja Hlinku 2, 94976 Nitra, \\ Slovak Republic \\ ${ }^{2}$ Slovak University of Technology in Bratislava, Vazovova 5, 81243 Bratislava 1, Slovak Republic
}

Received: 7 December 2016

Accepted: 22 January 2017

Published online: 8 March 2017

\begin{abstract}
Knowledge of surface runoff characteristics allows creating better conditions for landscape management, whether rural or urban. We focused on a determination of a volume of surface water runoff and it velocity in this paper. A direct measurement was done on an experimental area with three different slopes in a laboratory. Results of direct measurements were compared with results from a model SMODERP and NRCS method used in GIS environment. The velocity of surface runoff was also calculated by a mathematical equation used in literature. The results of surface runoff volume from GIS were equal in all cases, but not the velocity. The results of SMODERP simulation and direct measurements are similar. The calculated velocity was the highest in case of first slope, and the lowest in other cases. Differences of the velocity varied in a range 1.10 $11.06 \%$. The volume of surface runoff varied more, mainly the results of NRCS Curve Number method in GIS (up to $41 \%$ ). The results show that the higher slope, the higher runoff velocity and volume is.
\end{abstract}

Keywords: surface runoff, velocity, volume, SMODERP, NRCS Curve Number method

\section{Introduction}

A development of technology, software and its spread via internet has an impact on its ease availability. It is applicable also to models with lower quality or models not suitable to all areas. Due to insufficient verification of model in the real conditions or laboratory conditions, at least the lower quality of the models could be.

Zhao et al. (2014) wrote that the correct understanding of the most important hydrological processes under different climate conditions or special study areas is fundamental, for either an appropriate creation of a new hydrological model or the correct choice among a large number of existing hydrological models.

The surface runoff and its characteristics depend mainly on amount of precipitation, amount of infiltrated water, surface accumulation of precipitation and interception (Muchová and Antal 2013). Those conditions then create the surface runoff, flood wave, soil erosion, soil water and groundwater storage, change of surface roughness, etc. Qian et al. (2016) mentioned that flow velocity is a crucial

\footnotetext{
* Corresponding author: Tatiana Kaletova

e-mail: tatiana.kaletova@uniag.sk
} 
indicator in the study of soil erosion. Eroded materials slowly decrement a capacity of water reservoirs (Kubinský et al. 2015); therefore, its initial purpose is progressively changed, eventually there is no more the water reservoir.

The surface roughness highly impacts the soil erosion process, as well as hydrological processes in the landscape, e.g., velocity of surface runoff. The rough surface has a lot of depressions and barriers, which decrement a transport capacity of a water body by the decrease of runoff velocity (Šinka and Moravčík 2015).

The aim of the paper is to compare direct measurement of surface runoff velocity and surface runoff volume in the laboratory with the results from model SMODERP and NRCS Curve Number (NRCS) method used in GIS environment. Also, the surface runoff velocity was calculated by the equations used in Slovakia.

\section{Material and methods}

\subsection{Direct measurements}

A physical hillside model for a simulation of surface runoff was constructed in the laboratory of Department of Water Resources and Environmental Engineering of Slovak University of Agriculture in Nitra. The simulated land use was fallow, and the slope of hillside was changed. The three slopes were simulated, and every simulation was repeated three times. Soil (Tab. 1) used for the simulation was from Malanta, Nitra region.

Water was applied from the tank with constant volume. The volume of surface runoff was collected in another tank, and measured after the simulation. The velocity of surface runoff was calculated from the measured time and length of trajectory (Németová 2016).

Tab. 1 Characteristics of soil (Németová 2016).

\begin{tabular}{ll}
\hline Locality & Malanta \\
\hline Soil texture class according to Novák & Loam \\
Soil type & Brown soil \\
Soil texture class & medium heavy soil \\
Soil particle size $-\mathbf{1}^{\text {st }}$ category $(\%)$ & $30-45$ \\
\hline
\end{tabular}

\subsection{NRCS Curve Number method in GIS environment}

The first calculation of the volume of direct runoff was made in ArcGIS 9.1 environment. The NRCS method was chosen and proceed according to the methodology developed by V. T. Chow (1964), adjusted to the conditions of Slovakia by Antal $(1985,1999)$, and steps published by Šinka and Kaletová (2012). We took NRCS numbers for bare soil and hydrological soil group B. The repeating of simulation wetted the soil surface, therefore we calculated with NRCS value for antecedent moisture condition class III.

\subsection{Model SMODERP}

The model SMODERP is a single-event physical-based model for simulating of overland flow and erosion at the field scale up to $1 \mathrm{~km}^{2}$. Topography, soil, vegetation and land use can vary along the slope. The model is used to estimate the volume, peak flow rate, velocity, and tangential stress of overland flow, etc. (Dostál et al. 2000). This physically based model that includes the processes of infiltration (Phillips equation), surface runoff (kinematic wave based equation), and surface retention (Kavka and Zajicek 2013). The input parameters were selected the same as parameters of physical model in the laboratory. 


\subsection{Calculations}

The direct numerical calculation of the surface runoff was based on the equation published by Hrádek (1989):

$$
v_{x}=\sqrt{m \cdot x \cdot\left(i_{d}-v_{i}\right) \cdot \sqrt{I}} \quad \text { Eg. } 1
$$

where $v_{x}$ is the velocity of surface runoff in a distance $\mathrm{x}[\mathrm{m} / \mathrm{s}], m(87 / \gamma)$ is a coefficient characterized surface roughness by Bazin, $i_{d}$ is a mean intensity of design precipitation $[\mathrm{m} / \mathrm{s}], v_{i}$ is a mean infiltration intensity $[\mathrm{m} / \mathrm{s}], I$ is slope $[\mathrm{m} / \mathrm{m}]$.

The equation (1) was adapted to condition of this research according to Šinka et al. (2015). The determination of the average infiltration rate is a time and financially challenging. Therefore, the part $\left(i_{d}-v_{i}\right)$ in the equation (1) was replaced by $\left(i_{d \cdot} \varphi_{O, P}\right)$, where $\varphi_{O, P}$ (coefficient of surface runoff volume) was determine as:

$$
\varphi_{O, P}=\frac{V_{O, P}}{V_{D, N}} \quad E q .2
$$

where $V_{O, P}$ is the volume of surface runoff $\left[\mathrm{m}^{3}\right], V_{O, P}$ is the volume of design precipitation $\left[\mathrm{m}^{3}\right]$. The results from direct measurements of surface runoff were used in the calculation of each slope. According to information from Mr. Šinka, the $\left(i_{d}-v_{i}\right)$ in the equation (1) was replaced by $\left(i_{d .} \varphi_{N}\right)$, where $\varphi_{N}$ is a replacement coefficient of surface runoff:

$$
\varphi_{N}=\frac{2 \cdot \varphi_{O, P}}{1+n_{h}} \quad E q .3
$$

where $n_{h}$ is a coefficient of a shape of peak flow hydrograph determined according to Hrádek (1981):

$$
\begin{array}{ll}
n_{h}=\frac{4}{3}\left(q_{D, 100} \cdot \varphi_{O, P}\right)^{0,25} \quad \text { Eq. } 4
\end{array}
$$

where $q_{D, 100}$ is an intensity of design rainfall with a time of repletion 100 years $\left[\mathrm{m}^{3} /\left(\mathrm{s}_{\mathrm{km}}\right)\right]$. The intensity was calculated from the volume of rainfall in the time on the area.

\section{Results}

The velocities and volumes of surface runoff were measured during each run. The same parameters as the hillside in the laboratory were used in the model SMODERP, and numerical calculation as well as in NRCS method. All the results were compared.

\subsection{Surface runoff velocity}

The measured velocity of surface runoff was different as others (Tab. 2). The differences are mainly up to +/- 10 per cent (Fig. 1). The calculated velocity in the slope $18.28 \%$ differ more. The results from the GIS environment have the highest differences compare to measure one. In this case were used the same equations ( 1 - 4) as in calculation, just with different Bazin roughness coefficient. One can see the impact of one coefficient on the total results. The value of surface roughness coefficient according to Bazin in the numeric calculation was selected 8 (rough soil) in the case of slope $18.28 \%$. In the second case it was 3 (soil after the tillage with plane surface), and in the third one 1.5 (tillage in slope). The value 3.5 of roughness coefficient according to Bazin was used in the calculation in GIS environment. The roughness coefficient according to Bazin is only briefly describes in the literature available for us. Therefore, it is necessary to have enough experiences to select the appropriate one. 
The results of the surface runoff velocity in other slopes are more comparable. The differences are up to $12 \%$. The highest differences are in the calculation in GIS environment.

Tab. 2 Results of the surface runoff velocity $[\mathrm{m} / \mathrm{s}]$.

\begin{tabular}{lcccc}
\hline Slope [\%] & $\begin{array}{c}\text { Direct } \\
\text { measurement }\end{array}$ & SMODERP & Calculation & GIS \\
\hline $\mathbf{1 8 . 2 8}$ & 0.0181 & 0.0179 & 0.0241 & 0.0356 \\
$\mathbf{2 8 . 0 0}$ & 0.0789 & 0.0801 & 0.0746 & 0.0729 \\
$\mathbf{4 0 . 2 8}$ & 0.1266 & 0.1345 & 0.1255 & 0.1406 \\
\hline
\end{tabular}

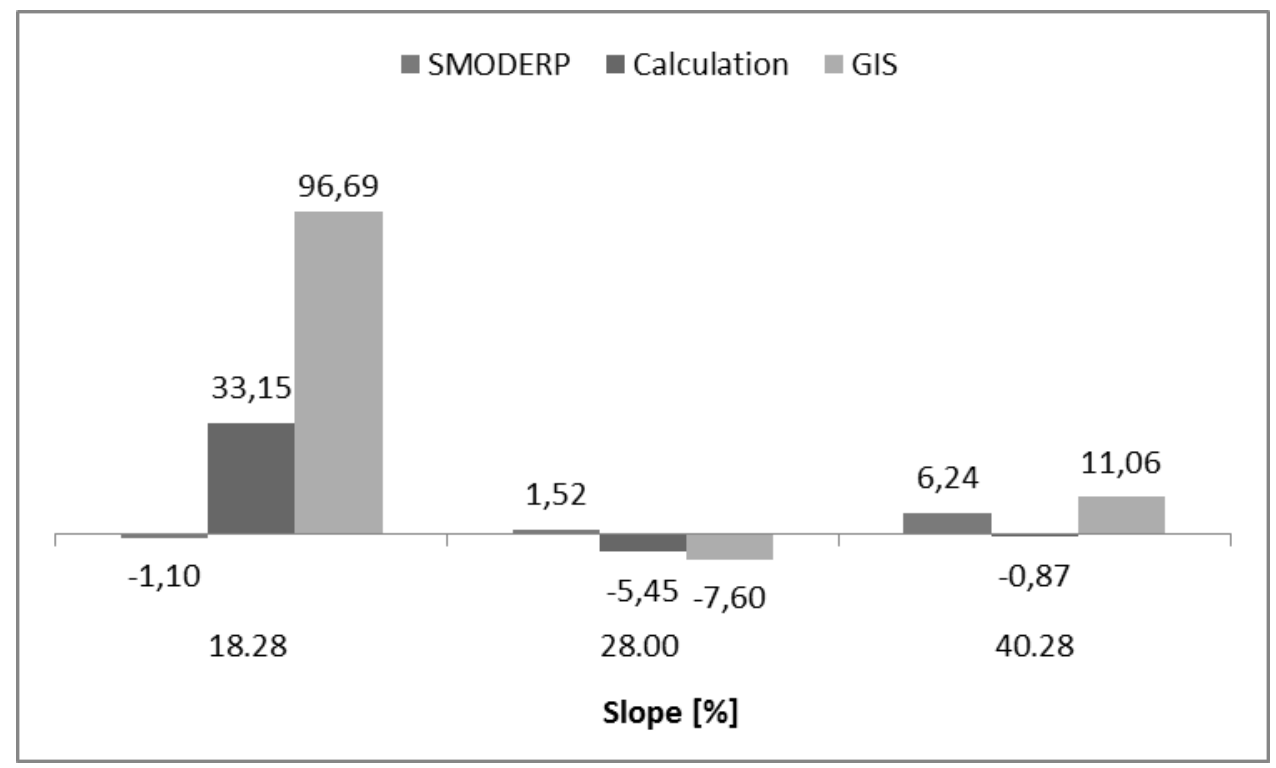

Fig. 1 The difference [\%] of modelled and calculated velocities compared to measured values.

\subsection{Surface runoff volume}

The direct measurements of surface runoff volume have the smallest values in the slope of $18.28 \%, 28.00 \%$, respectively. The results of NRCS method have the constant values in all slopes. It is given by the methodology of the calculation, where the slope of hillside has no impact on the calculated volume of runoff. The differences between direct measurements and results of model SMODERP are small. The volume of surface runoff during the measurements is $4.62 \%$ smaller as the modelled one in case of slope of $18.28 \%$, and the $2.81 \%$ in case of slope of $28.00 \%$. The results of NRCS method were higher about $40.65 \%, 15.66 \%, 2.04 \%$, respectively.

Tab. 3 Results of surface runoff volume [ml].

\begin{tabular}{lccc}
\hline Slope [\%] & Direct measurement & SMODERP & NRCS \\
\hline $\mathbf{1 8 . 2 8}$ & 342 & 357.8 & 480 \\
$\mathbf{2 8 . 0 0}$ & 415 & 426.67 & 480 \\
$\mathbf{4 0 . 2 8}$ & 490 & 425 & 480 \\
\hline
\end{tabular}

\section{Discussion}

The results show that the higher slope, the higher runoff velocity and volume is. The same results describe Liu et al. (2006). Also, Kondrlová and Muchová (2008) wrote, that with higher slope 
of hillside, the higher runoff velocity and transport energy of the moving water on the soil surface; therefore, there is the cratering of soil particles and nutrients. Significant differences in the calculated velocity of runoff in comparison with direct measurements, the results from the model and GIS can be attributed to the need to estimate the correct roughness coefficient, what describe Šinka et al. (2015). Changing only this one parameter in the calculation had a significant impact on the results of the velocity. Govers et al. (2000) report that the outlet for measuring the rough surface is difficult and we can expect relatively large surveying errors. It is therefore necessary to do some additional direct measurements, the results of which will be applied for conditions in Slovakia.

Achieved results support the applicability of the model SMODERP in our conditions. Recorded real difference measurements and modelling are still lower than indicated Kavka (2011), which compares the results from the model results SMODERP CN method in the environment Watershed Modelling System (WMS). In his case, the volume of runoff by NRCS method was $79.54 \%$ lower than in the model SMODERP. The author points to the difference of time they work with different models, which in our case was not a problem.

The NRCS method as itself was developed for the slopes of less than $5 \%$, and this range does not influence the curve number to any great extent (Boonstra 1994). It is allowed to grow crops at the slopes up to $7^{\circ}(12.28 \%)$, in case of alternate used at the slopes up to $12^{\circ}(21.25 \%)$ in Slovakia (Látečka and Muchová 2005). Also, Muchová et al. (2016) recommend to growth not growing erosion-prone crops at the slopes of more than $5^{\circ}(8.75 \%)$. During the time the crops don't cover the soil surface, the values for bore soil should be applied. Therefore, into the NRCS method should be introduced the impact of the slope. There were very few attempts made to include a slope factor in the CN method, although slope has strong influence on runoff volume (Ebrahimian et al. 2012).

\section{Conclusions}

The model SMODERP, NRCS-method applied in GIS environment, direct measurements and calculations were used in this study. Comparison of the results shows, that values from all methods are similar, and the differences are minimal. The results of runoff velocity were mainly in range of 1.10 $11.06 \%$. The results of runoff volume varied more, mainly the results of NRCS-method in GIS. It is in the range up to $40.65 \%$.

The results show that the higher slope, the higher runoff velocity and volume is. There is necessary to do other experiments. In general, it is possible to use all calculation presented in the paper, but with an appropriate experiences. After that, it could be used for the prediction of flow rate from the rains or for a design of the flood and soil erosion protection.

\section{References}

Antal J (1985) Ochrana pôdy a lesotechnické meliorácie II: Návody na cvičenia. Príroda Bratislava. Antal J (1999) Agrohydrológia. SPU Nitra.

Antal J et al. (2014) Hydrológia pol’nohospodárskej krajiny. SPU Nitra.

Boonstra J (1994) Estimating peak runoff rates. Drainage principles and applications, pp. 111-143. ILRI Publication 16. Wageningen, The Netherlands, ILRI

Chow VT (1964) Handbook of Applied Hydrology. McGraw Hill New York.

Dostál T, Váška J, Vrána K (2000) SMODERP - A Simulation Model of Overland Flow and Erosion Processes. Application of Physically Based Models. pp. 135-161. doi: 10.1007/978-3-662-042953_8

Ebrahimian M, Nuruddin AAB, Soom MABM, Sood AM, Liew JN (2012) Runoff Estimation in Steep Slope Watershed with Standard and Slope-Adjusted Curve Number Methods. Polish Journal of Environmental Studies 21(5):1191-1202. 
Govers G, Takken I, Helming K (2000) Soil roughness and overland flow. Agronomie 20:131-146. doi: 10.1051/agro:2000114

Hrádek F (1981) Aplikace genetického vzorce intenzitního typu pro výpočet kulminačních prutoku Q100 na malých povodích. Praha VŠZ.

Hrádek F (1989) Řešení maximálního povrchového odtoku na modelovém povodí. Vysoká škola zemědělská v Praze.

Kavka P, Zajicek J (2013) Soil erosion model SMODERP - 1D and 2D modelling. SGEM2013 Conference Proceedings, June 16-22, 2013. pp 895-902. doi:10.5593/SGEM2013/BB2.V1/S11.037

Kavka P (2011) Kalibrace a validace modelu SMODERP. České vysoké učení technické v Praze.

Kondrlová E, Muchová Z (2008) Priestorové analýzy v GIS pri posudzovaní ohrozenia územia vodnou eróziou. Študentská vedecká konferencia FZKI 2008, Nitra - 22. April 2008. SPU Nitra, p. 78-84.

Kubinský D, Weis K, Fuska J, Lehotský M, Petrovič F (2015) Changes in retention characteristics of 9 historical artificial water reservoirs near Banská Štiavnica, Slovakia. Open Geosciences 7(1):880887. doi: 10.1515/geo-2015-0056

Látečka M, Muchová Z (2005) Pozemkové úpravy a cesty Pozemkové úpravy a cesty. SPU Nitra.

Liu Y B, Gebremeskel S, De Smedt F, Hoffmann L and Pfister L (2006) Predicting storm runoff from different land-use classes using a geographical information system-based distributed model. Hydrological Processes 20:533-548. doi:10.1002/hyp.5920

Muchová Z, Antal J (2013) Pozemkové úpravy. SPU Nitra.

Muchová Z, Leitmanová M, Petrovič F (2016) Possibilities of optimal land use as a consequence of lessons learned from land consolidation projects (Slovakia). Ecological engineering 90:294-306. doi:/10.1016/j.ecoleng.2016.01.018

Németová Z (2016) Modelové riešenie povrchového odtoku z pol’nohospodársky využívaného územia. SPU Nitra.

Qian F, Cheng D, Ding W, Huang J, Liu J (2016) Hydraulic characteristics and sediment generation on slope erosion in the Three Gorges Reservoir Area, China. Journal of Hydrology and Hydromechanics. 64(3):237-245. doi: 10.1515/johh-2016-0029

Šinka K, Muchová Z, Konc L' (2015) Geografické informačné systémy v priestorovom plánovaní. SPU Nitra.

Šinka K, Kaletová T (2013) Determining the characteristics of direct runoff from real rain using GIS environment. Acta horticulturae et regiotecturae 16(2):48-52.

Šinka K, Konc L', Muchová Z (2015) Výpočet charakteristík povrchového odtoku s využitím GIS a modelu DesQ-MaxQ. Krajinné inžinierstvo - problémy, trendy a perspektívy 2015, meeting: 13. November 2015. p. 74-83.

Šinka K, Moravčík L' (2015) Stanovenie drsnosti povrchu pôdy a jej význam pri modelovaní vodnej erózie. Environmentálne indexy, oblasti ekologického záujmu a ekosystémové služby v krajine. VUPOP, p. 43-48.

Zhao N, Yu F, Li C, Wang H, Liu J, Mu W (2014) Investigation of Rainfall-Runoff Processes and Soil Moisture Dynamics in Grassland Plots under Simulated Rainfall Conditions. Water 6:2671-2689. 